\title{
Human Resources Management to Create Environmental Occupational Health and Safety (Eosh) During the Covid-19 Pandemic

\author{
(Case Study on the Toll Road Business Entity in Kuala Tanjung - \\ Tebing Tinggi - Parapat)
}

\author{
Dewi Ira Prasetiawati \\ H.M. Ahman Sya \\ Agung Wahyu Handaru \\ ira.dewi.99999@gmail.com \\ State University of Jakarta
}

\begin{abstract}
This study aims to explain, reveal facts, and obtain empirical findings on Human Resource Management to create Environmental Occupational Health and Safety (EOSH) during the Covid-19 pandemic in Kuala Tanjung Tebing Tinggi Parapat Toll Road Business Entity which is focused on on the management of human resource to create environmental occupational health and safety during the Covid-19 pandemic. The research was designed with a qualitative approach using the NVIVO analysis test tool. The data was collected using interview, observation, and document review methods. Research informants were Project Owners, Technical Supervision Consultants, Contractors, and Implementers in the field. The validity of the data quality test was carried out through triangulation of data, sources, methods, and time. Research results and findings of an environmental occupational health and safety system are absolutely necessary in every industry, this needs to be carefully designed before work begins. Because human resources are the main asset, periodic rejuvenation is necessary. HR competency management is absolutely necessary to understand EOSH so that they have the enthusiasm to achieve targets. In the company, innovation is one of the keys to the company's success, it is about how the human resource management are able to provide an attractive reward system, and construct activities which involve many parties. It is necessary to carry out risk management and maintain health protocols to prevent the spread of covid-19 so that work can be completed under any conditions.

Keywords: Human Resources Management, Environmental Occupational Health And Safety (EOSH), Covid-19 Pandemic
\end{abstract}

DOI: $10.7176 / \mathrm{EJBM} / 14-3-01$

Publication date: February $28^{\text {th }} 2022$

\section{INTRODUCTION}

Infrastructure development is one of the Indonesian government's programs in equitable development for economic growth. With equitable development, it is expected to increase Indonesia's overall economic growth. The development that has been carried out so far is considered quite successful in improving the standard of living of the Indonesian people. The rapid growth is marked by the development of the industrial sector, settlements, as well as the widening of urban areas to suburban areas, resulting in mixed local and regional traffic. This condition can cause traffic jams on the main roads and create a high cost economy.

In the current era of globalization, the problem of readiness to move to Industry 4.0 lies in human resources and equity, some industrial sectors in Indonesia are still far from Industry 4.0. For example, in the agrarian industry, there are still farmers using hoes. Though some farmers have entered Industry 4.0, not all of them have mastered how to use a computer. Another problem lies in the large number of Indonesians who do not have adequate human resources, because it is estimated that the entry of this industry will cut human labor with low human resource capabilities and possibly increase the unemployment rate. One of the ways the government deals with this is starting with infrastructure development for equitable distribution in various sectors and improving the economy.

In an effort to build infrastructure, it is necessary to have resources with good competence and performance as well as professionals in the field of construction development that support the process of carrying out the work. In the era of globalization, the issue of human resources has become the focus of both government and private organizations. Human resource is a valuable asset owned by an organization and it also determines the success of achieving organizational goals. In achieving success, an organization needs a strong foundation in the form of competent human resources. These competencies are in the form of knowledge, skills, and attitudes which are the key components in management which play an important and strategic role in improving employee performance. In addition, the purpose of increasing competence in the organization is due to the demands of work as a result of advances in science and technology as well as the demands of the community who ask for easier, cheaper, and 
faster services.

The implementation of the project was constrained by very severe conditions, namely the emergence of the Covid-19 pandemic where the disease outbreak spread very quickly that it greatly disrupted the project development process in the field. The disease outbreak started in Wuhan, China at the end of 2019 and began to spread rapidly throughout the world. In Indonesia, this outbreak only began to be felt in the 1 st quarter of 2020 , namely March 2020, where there were already victims due to the COVID-19 pandemic. This was followed by the emergence of economic crises around the world due to the discontinuation of business processes from the emergence of the pandemic. In Indonesia, this condition took place relatively quickly where negative economic growth began in the 2 nd quarter of 2020 and continued in the 3rd quarter of 2020. So practically, in October 2020, Indonesia entered a period of economic crisis. In addition, infrastructure development must continue and be completed as one of the National Strategic Project programs for infrastructure development. This condition is certainly very significant and becomes a separate problem for the sustainability of the toll road business itself.

Based on the background of the problem, the researcher conducted a research process by focusing on a case study in one of the Toll Road Business Entities for the Kuala Tanjung Tebing Tinggi Parapat Toll Road in the hope that a solution to the existing cases related to the sustainability of the toll road business with all its problems and innovations and efforts made to get the problem solving in question is found. A company in its journey will certainly face a situation where changes are needed in the company. The transformation of core business will be successful if it involves all elements of the company and is in line with the company's vision and mission (Wikumurti, 2019). Good planning elements in the company in terms of quality and quantity can support the achievement of company goals. The element referred to here is human resources. (Handayani and Ilmawan, 2017).

The COVID-19 pandemic has impacted many aspects of life. One of them is how a company or organization can survive in critical times. The application of Work From Home means that the human resource management function has changed from traditional to all digital (Rusilowati, 2020). A new culture needs to be implemented as a strategy for the survival of the organization. Training needs to be done to adopt the new culture (Annalia, 2020). Adopting a new culture is not an easy thing. However, the COVID-19 pandemic can be a momentum for companies to improve in order for its business to continue. The contribution of good human resources is used to support these changes. (Silalahi, 2020). The COVID-19 pandemic demands that all components in the organization undergo changes. In the process of change, it is not uncommon for some parties to feel uncomfortable, which results in stress that arises. Now, human resource management is also responsible for assisting these parties in managing stress. Stress management can be done by diverting distress into eustress so that a person can still come up with productive creative ideas (Muslim, 2020). Every business person must be faced with a goal. On the way to achieving these goals, every aspect of a business will have one or more risks. These risks have their respective levels and ownership or are called owner risk (Santoso, Budi, and Sahid, 2017). Human Resource Management is one aspect that needs to be reviewed for risk. This risk must be managed so that it can be used as a preventive effort to minimize the negative impacts that arise (Kembuan, Mandigi, and Lumeno, 2019).

We are already familiar with the aspects of Occupational Safety and Health in the construction world. In fact, the current project implementation targets are not only focused on precise quality, time, and cost. But also zero accident and zero fatality. Project management commitment to Occupational Safety and Health aspects greatly affects project performance (Widari, Zulfhazli, and Rizky, 2018). The outbreak of the COVID-19 virus, which became a global pandemic, began to enter Indonesia around March 2020. The Covid-19 virus, which is able to spread quickly, makes people have to keep their distance. This has an impact on various aspects of life. In the field of education, children who are still vulnerable to being exposed to the virus are required to take part in online teaching and learning activities. Teachers, students, and parents face new challenges so that lessons can continue as normal. Education in the new normal era requires reliable human capital contributions as well as adequate facilities and infrastructure (Arafah and Bahri, 2020).

The effects of the pandemic are also being felt in the business world. The current situation causes buyers and sellers to be unable to meet face-to-face. The buying and selling transactions are then carried out online so that now the existence of online business platforms is increasingly known to the wider community (Taufik and Ayuningtyas, 2020). The construction world has not been spared the impact of the COVID-19 pandemic. A risk assessment is absolutely necessary to overcome a crisis that is very likely to occur in the midst of this pandemic (Sihombing, 2020). Construction accidents that occurred throughout 2017 to the first quarter of 2018 experienced a drastic decline from the second quarter to the end of 2018. One of the keys is safety leadership which is currently being developed and implemented in a number of construction service companies. In terms of work accidents, data shows that 2017 was the worst year in the history of Occupational Safety and Health (OSH) in Indonesia since Law No. 1 of 1970 concerning Occupational Safety which has been enacted since January 12, 1970. There was a surge in the number of work accidents in 2017 in the construction sector due to the rise of work accident cases that occurred throughout 2017 and even lasted until the first quarter of 2018. Accident cases occur, especially work accidents in construction projects of elevated toll roads which are included in the National Strategic Project with funding sourced from the State Budget (APBN) and State Equity Participation (PMN). To reduce the rate of the 
work accident which is increasing, an investigation was held. The Ministry of Public Works and Housing through the Ministerial Decree of The Ministry of Public Works and Housing No.66/KPTS/M/2018 formed the Construction Safety Committee on January 29, 2018.

\section{Research Focus and Sub Focus}

1. Implementation of the Environmental Occupational Safety and Health System before and after the Covid-19 pandemic.

2. HR Competency Management in the field of EOSH

3. Toll Road Business Entity innovation in the field of EOSH in overcoming the challenges of the problem

4. Toll Road Business Entity Performance Results in the last 2 years

\section{Problem Formulation}

The formulation of the problem in this study leads to problems related to the management of human resources to realize Environmental Occupational Safety and Health in the joint venture Toll Road Business Entities in the Covid-19 pandemic condition and are associated with the sub-focuses studied which include:

1. How is the implementation of the Environmental Occupational Safety and Health System before and after the Covid-19 pandemic?

2. How is the management of HR competencies in the EOSH field to achieve company goals and targets from both the TRBE and the Parent Shareholder?

3. What triggers the emergence of TRBE innovation in the EOSH field in overcoming the challenges of problems in order to be able to analyze problems that arise against existing conditions so that they can bring up problem solving solution to achieve TRBE targets?

4. How are the results of TRBE's performance in the last 2 years based on the progress of land procurement and construction, and what has been done to improve company performance, as well as how the ongoing process is related to improving company performance?

\section{LITERATURE REVIEW}

\section{Human Resource Management}

Wikumurti (2019) through his journal stated that the core business of a company can be changed. To ensure that these changes can run well, the role of human capital is very large here. Socializing and transparently explaining the details of changes to every element in the company is the responsibility of the Human Capital Division. One indicator of the success of the human resource transformation process is seen from the results of employee engagement and satisfaction.

The Covid-19 pandemic is a momentum to be able to make changes and improve. In business continuity in any condition or situation, the organization must be able to make new breakthroughs, innovations, and the right strategy. To support organizational goals, the contribution of HR to achieve organizational progress and success, researchers argue that there are three concepts that are required by HR to do, namely the concept of adopt, adapt and adept (Silalahi, 2020).

Procurement of human resources in a company needs to be carefully planned (Handayani \& Ilmawan, 2017). The main focus in the planning is to compare the needs and availability of human resources in a company. If there is a surplus of resources, it is necessary to do a layoff. On the other hand, if the availability of human resources has not been able to be met, then a recruitment process is needed. Knowledge, abilities, and skills are used as benchmarks in finding the right personnel to fill a certain position.

Annalia (2020) explained that human resource as a company's valuable asset, needs to be properly maintained. In order for individuals to continue to develop while working from home, companies provide a lot of training. Training can open up new knowledge for workers so that they are able to think more critically, creatively, and skilfully.

\section{Risk Management}

In every job or activity, there must be some risks that will occur. These risks can have both positive (opportunity) and negative (challenge) impacts. Risks that have a negative impact need to be done with risk management so that the project can still achieve the objectives, namely: the right quality, time, and cost (Santoso, 2017).

The dominant risk is then reviewed again to determine which party is responsible for tackling it. The results showed that the Contractor was most responsible for the dominant risk followed by Project Owner and Supervisory Consultant.

Risk management practices are not only found in domestic projects, but also in International Joint Operation. The cooperation formed surely has a goal. In this case, it is the construction of the Manado-Bitung Toll Road infrastructure. To achieve these goals, the project is faced with various aspects of risk. This risk must be managed so that it can be used as a preventive effort to minimize the negative impacts which will arise (Kembuan, Mandigi, 
and Lumeno, 2019).

\section{Occupational Safety and Health}

Occupational Safety and Health aspects have a major influence on the performance of construction workers. For example the Manhattan Mall and Condominium development project. Construction development performance is strongly influenced by Occupational Safety and Health commitments and policies. Project Management is very concerned about Occupational Safety and Health (OSH) to improve worker performance so that the implementation of construction work can run well and on target. In the implementation of Occupational Safety and Health $(\mathrm{OSH})$ required regulations and procedures that apply must be applied in the field during the implementation of the project and adjusted to those that have been determined by the company's own OSH management (Widari, Zulfhazli, and Rizky, 2018)

In this journal, the researchers try to identify the implementation of occupational safety and health (OSH) aspects in workers. The results showed that occupational safety and health variables had a positive influence on the performance of workers. It is expected that the company is able to maintain or improve aspects of Occupational Safety and Health $(\mathrm{OSH})$ so that maximum work results are obtained.

\section{Impact of Covid-19 Pandemic}

In the face of the covid-19 pandemic, an organization will react to existing challenges and make changes. The changes will help an organization survive the covid-19 pandemic. There are several stages to make changes, commonly referred to as PDCA (Plan, Do, Check, Act). As long as the changes are implemented, there will certainly be some corrections, so that further SDCA (Standardize, Do, Check, Act) can be made. After the SDCA is undertaken, then the activity can return to the PDCA cycle (Arafat and Bahri, 2020).

The application of New Normal in a region can be done if at least the following requirements have been met, namely: transmission can be controlled, the existence of adequate health facilities, guarantee of preventive measures in the work environment, prevention of imported cases of covid, and the collective participation and public awareness. The alternative that the government can do if New Normal is not ready is through the transition period.

The increasing number of covid-19 cases and the establishment of Jakarta as the epicentrum of the spread of the covid-19 virus made the Jakarta Provincial Government take steps to reduce the rate of spread. The local government through the Jakarta Governor's Instruction Number 16 of 2020, on increasing vigilance against the risk of transmission of Covid-19 infection, restricts activities outside the home. Some shopping and tourism centers have been forced to close.

The journal done by Taufik and Ayuningtyas (2020) shows data on the areas of activities affected by the covid-19 pandemic, especially in DKI Jakarta Province, among others: 1) Primary, Secondary and Higher Education; 2) Trade; 3) Online transportation; 4) Hospitality; 5) Tourism; and 6) Pharmaceuticals and Health Products.

It is undeniable that the Construction Work Industry is significantly affected by the Covid-19 pandemic both business continuity and the implementation of work in the field. This is a challenge for construction business owners to have a strategy to continue in the midst of a pandemic. Companies are required to conduct risk assessments to find solutions. Companies are required to develop businesses and innovate following technological advances (Sihombing, 2020).

\section{RESEARCH METHOD}

\section{Time and Place of Research}

The research place was conducted on the Toll Road Business Entity project, namely the Kuala Tanjung - Tebing Tinggi - Parapat toll road project, North Sumatra. The study was conducted from April 2020 to December 2022. The initial research was conducted in mid-2020 where the coronavirus began to spread almost in all countries in the world including Indonesia and after going through a grand tour of observation, researchers submitted dissertation proposals. Based on the initial study, it will be deepened to be able to produce a more accurate analysis on this case study.

\section{Research Methods and Procedures}

This research applied qualitative approach. Anselm Strauss and Julliet Corbin (2007: 1) stated that qualitative research is a type of research whose findings are not obtained through statistical procedures or other forms of calculation. This qualitative research is research that can be used to examine people's lives, history, behavior, organizational functionalization, social movements, or kinship relationships. Qualitative research is an inquiry strategy that emphasizes the search for meaning, understanding, concepts, characteristics, symptoms, symbols and descriptions of a phenomenon, focus and multimethod, natural and holistic; prioritize quality, use several ways, and presented narratively. As the beginning of research, methods are used by planning and designing research and 
preparing through data collection and sharing, such as:

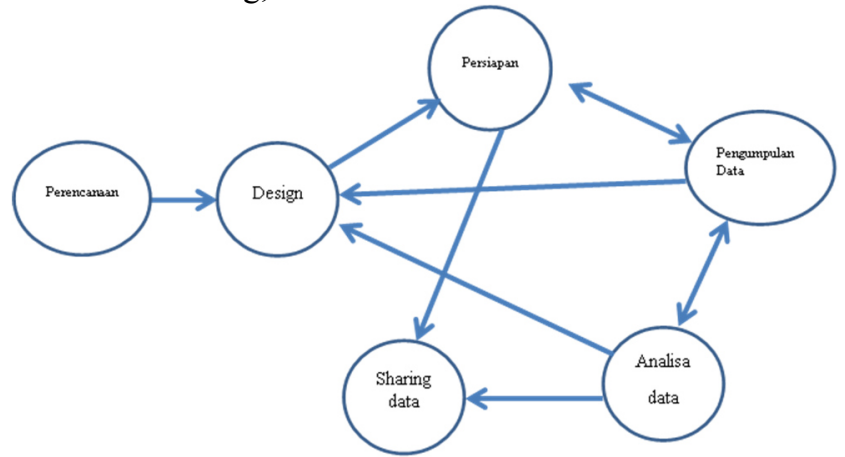

Figure 1. Research Process

Data Analysis Procedure

As an overview, the research design can be seen in figure 2:

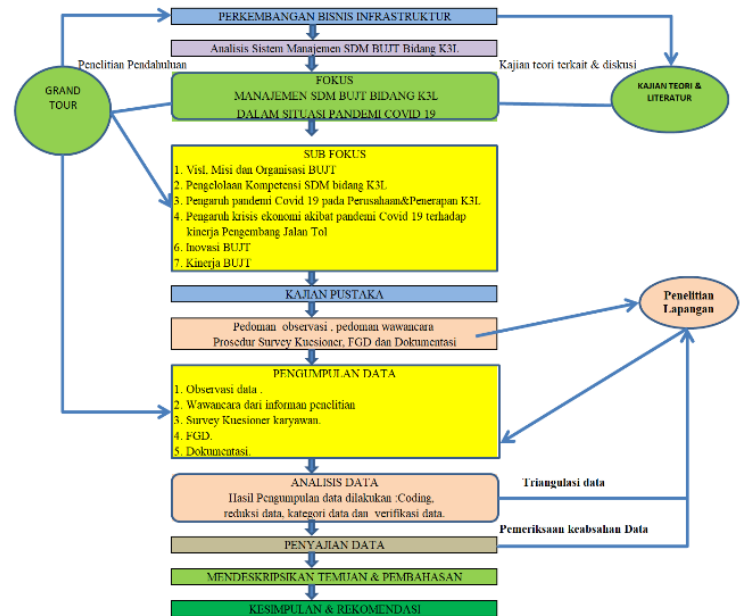

Figure 2 Research Design

\section{RESULTS AND DISCUSSIONS}

The number of people exposed to the covid-19 virus in Indonesia is undeniably increasing every day. Since the virus was first discovered in Indonesia in March 2020, it has spread rapidly. Based on the graph in the image above, the spike in cases occurred in January 2021 and June to July 2021. Jakarta, as an epicentrum of the spread of the covid-19 virus, until now is still the region with the most cases, reported through the covid19.go.id page. Government efforts to trigger a chain of spread of the virus are increasingly aggressive. The implementation of Work From Home and physical distancing is still the main step to reduce the rate of spread of the virus. In addition, the discovery of the covid-19 vaccine makes the government more confident that this outbreak can be resolved soon. But now, the world is faced with a new challenge, namely the emergence of various variants of the covid19 virus. This new variant is claimed to be more contagious and deadlier. Ministry of Health vaccination spokesman dr. Siti Nadia Tarmizi, M.Epid revealed that the new variant of covid-19 has a higher transmission rate, which is up to $75 \%$. He further appealed to the public to continue to comply with the government's advice to reduce mobilization.

\section{Pandemic to Occupational Safety and Health}

It has been two years in a row that World OSH Day is celebrated in the atmosphere of the covid-19 pandemic. In commemoration of the day, ILO held an online discussion themed on OSH investment in Indonesia. The government is using regulations and the issuance of social security during the crisis due to the pandemic, as one form of investment in the field of OSH. The ILO report entitled "Anticipation, Preparation, and Response to Crisis. Invest Now in a Tough OSH System," said that preventive measures and risk management studies were important in dealing with the crisis due to the COVID-19 pandemic. The government's commitment to tackling COVID-19 involves employers' and workers' unions. Before the pandemic took place, the focus of OSH was more on the safety aspect, now the health aspect is starting to be improved. 


\section{Implementation of Covid-19 Prevention Procedures at PT. Hutama Marga Waskita}

Since the emergence of the first case of Covid-19 in Indonesia in February 2020, the number of confirmed positive cases has continued to increase to date. Thus, it has been more than a year since the pandemic hit Indonesia. However, the economy cannot be allowed to continue running sluggishly. To restore the economy, companies must continue to operate in tandem with this pandemic outbreak. Toll Road Business Entities are no exception as actors in construction activities. Through a circular from the Toll Road Regulatory Agency, then TRBE issued Emergency Response Procedures to Prevent the Spread of the Corona Virus (Covid-19) in the Office and TRBE Project Environment Number: 001/PROSEDUR-HMW/III/2020 dated March 23, 2020. The procedure comprehensively describes the mechanism for preventing the corona virus both in the TRBE and the project environment, things that need to be considered when traveling, as well as things that need to be done if there are workers who become suspect of the corona virus. Efforts to prevent the Covid-19 virus are carried out in three events, namely: promotive, preventive, and curative efforts. Promotive prevention efforts include the installation of banners and posters regarding information related to Covid-19. Socialization of the prevention of the Covid-19 virus is also part of the promotive effort.

\section{Data Reduction}

The results of data reduction in this dissertation aim to reduce the number of data records by eliminating invalid data or generating summary data and statistics at different levels of aggregation for various analyses (Hammersley, 2018).

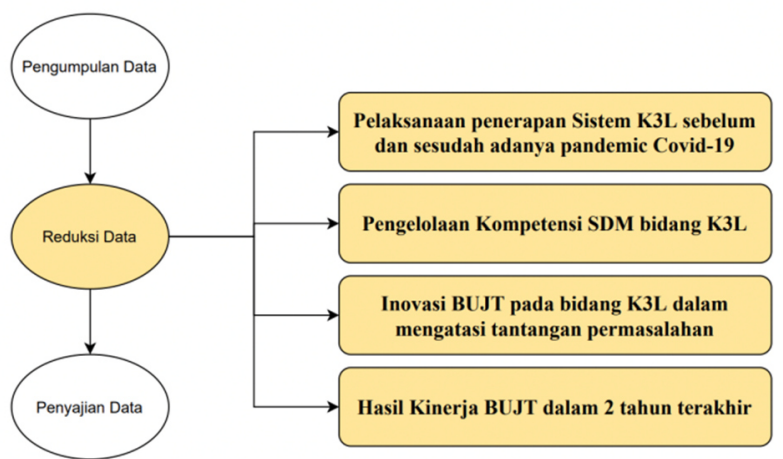

Figure 3 Data Reduction

Implementation of the Environmental Occupational Safety and Health System before and after the Covid19 pandemic.

1. So far, the management of HR competencies in the EOSH field at TRBE is limited to the HSE team, there is no comprehensive training for each employee. The Organization of the Occupational Safety and Health Committee should be formed. The Occupational Safety and Health Development Committee (OSHDC) is an auxiliary body in the workplace which is a forum for cooperation between employers and employees to develop cooperation, mutual understanding and effective participation in the implementation of occupational safety and health. The formation of the OSHDC organization is a mandate in Law no. 01 of 1970 where OSHDC is tasked with providing considerations and can assist the implementation of efforts to prevent work accidents and occupational diseases within the Company and can provide effective socialization to workers. In order to comply with the Law, the Company must establish a OSHDC Organization within the TRBE.

2. The person who is most responsible for the competence of HR in the field of EOSH is the highest level in the company, namely the Main Director, because he has the full power over the delegation of authority to run it.

3. During this pandemic period, many seminars were held to increase HR competence through video conference/zoom. Video conferencing is very effective in terms of time so there is no need to think about travel time. Within 1 day, we are able to attend 2 to 3 seminars. But the weakness is that there is no direct interaction between the participants and the presenters of the material, resulting in the inability to practice what is in the material directly.

4. The management of HR competencies in the EOSH field is sufficient at this time. Maybe in the future it can be improved further with new regulations that have been passed. We must continue to grow with the changes that exist. 


\section{Research Findings}

1. Evaluation of EOSH Implementation before the Covid-19 Pandemic

a. Plan

Most of the respondents do not have information regarding the planning for the implementation of the Environmental Occupational Safety and Health System. The percentage of answers "No" on each point exceeds $50 \%$. This happened because the planning process only involved the Division of Environmental Occupational Safety and Health.

b. Socialization

The socialization regarding the implementation of Environmental Occupational Safety and Health has been carried out well. Prior to the implementation of the regulations, experiments have also been carried out for a certain period of time. So that all elements are more familiar with these regulations. The percentage of "Yes" answers in points 1 and 2 exceeds 50\%. Meanwhile, for each change that occurred, most of the respondents did not know about the socialization that was carried out. The percentage of "Yes" answer is less than $50 \%$.

c. Implementation

The implementation of Environmental Occupational Safety and Health system has been carried out well. Respondents answered "Yes" to almost all points in the questionnaire. Meanwhile, due to the lack of implementation violation complaints services, the answer "No" is in the range of $67.59 \%$.

d. Evaluation

Each regulation implementation is evaluated periodically. In addition, an evaluation is also carried out every time a new regulation emerges from the government. This can be proven by the respondents' answers to the "Yes" option being above $50 \%$ for each point.

2. Evaluation of EOSH Implementation during the Covid-19 Pandemic

a. Plan

Still the same as before the pandemic, the majority of respondents do not know the planning process for implementing Environmental Occupational Safety and Health. This is proven by the lack of "Yes" answers in points 1 to 3 , which is less than $50 \%$. As for points 4 to 6 , the majority of respondents answered "Yes", because it was in accordance with what was applied by PT. Hutama Marga Waskita. The respondent's assessment for the answer "Yes" is already above 50\%.

b. Socialization

The socialization regarding the implementation of Environmental Occupational Safety and Health has been carried out well. Prior to the implementation of the regulations, experiments have also been carried out for a certain period of time. So that all elements are more familiar with these regulations. The percentage of "Yes" answer in points 1 and 2 exceeds 50\%. However, the percentage during the pandemic is higher than before the pandemic. This indicates that the company is conducting socialization more actively. Meanwhile, for each change that occurred, most of the respondents did not know about the socialization that was carried out. The percentage of "Yes" answer is less than $50 \%$.

c. Implementation

Most of the respondents answered "Yes" to each item of the implementation of Environmental Occupational Safety and Health during the COVID-19 pandemic. This is proven by the percentage that is above $50 \%$.

d. Evaluation

Each regulation implementation is evaluated periodically. In addition, an evaluation is also carried out every time a new regulation emerges from the government. This can be proven by the respondents' answers to the "Yes" option being above $50 \%$ for each point.

3. Evaluation of HR Management due to the Covid-19 Pandemic

a. Changes of Working Procedure

Most respondents agree that the COVID-19 pandemic has brought about a change in the way they work. For this item, the percentage of "Yes" answer are all above 50\%. Respondents considered that the change of working procedure was almost balanced between difficult and not difficult. The two answer choices "Yes" and "No" are close to $50 \%$ each.

b. Skill Development Facility

The majority of respondents agree that the company provides facilities in the form of skill development. This can be seen in item numbers $6,7,8$, and 10. The weight of the "Yes" answer is all ranged above $50 \%$.

Meanwhile, the impact of change and innovation still makes some respondents feel uncomfortable. The weight of the answer "No", is greater than the answer "Yes" which is $62.04 \%$.

4. Evaluation of Human Resource Competency Management in the Field of Environmental Occupational Safety and Health

a. Targets in the Field of Environmental Occupational Safety and Health

Most respondents agree that Environmental Occupational Safety and Health should have a target. $87 \%$ of 
respondents gave the number 8 , from a scale of 1-10. A small portion of the rest gave ratings of 6 and 7.

b. Competency Management in the Field of Environmental Occupational Safety and Health

Respondents assessed that the management of competencies in the field of Environmental Occupational Safety and Health needed to be done. Competency management can be in the form of training. This training is tailored to the field of work of each individual. In addition, any training provided will be evaluated. More than $50 \%$ of respondents gave a rating above 8 , from a scale of $1-10$.

c. Reward related to Implementation of Environmental Occupational Safety and Health

The training also has its own milestone. So that every accomplishment obtained by a workforce will be given an award. Respondents gave an almost balanced value on the scope of the reward. A total of $58.3 \%$ of respondents gave an assessment at number 9.

5. Innovation of Toll Road Business Entity in the Field of Environmental Occupational Safety and Health in Facing Challenges

a. The Importance of Innovation During Pandemics (1)

A total of $92.6 \%$ of respondents think that innovation was needed by PT. Hutama Marga Waskita to be able to survive during the covid-19 pandemic. The assessment given by the respondent is at the number 9 , from a scale of $1-10$.

b. Implementation of Innovation during the Pandemic

Every workforce has the right to contribute innovation to the company. Nearly half (45.4\%) of the samples were tested, scoring at 8 , from a scale of 1-10. However, the innovation certainly has limitations that can be in the form of time or cost. Responses from respondents were distributed almost evenly on assessment numbers 7,8 , and 9 . To encourage every workforce to continue to innovate, TRBE provides stimulus. The stimulus is in the form of reward for workers whose innovations can be applied in the company environment. A total of $61.1 \%$ of respondents gave a score of 10 .

Innovation means a change in the way of working. Any changes will inevitably take the individual out of their comfort zone. $70.4 \%$ of respondents agreed that the change made them uncomfortable. Here the role Human Capital is very crucial in maintaining work productivity in the midst of changes that occur. During the process of implementing innovation from the beginning, the idea of innovation to monitoring and evaluation needs the supervisory role of all elements in the company. $61.1 \%$ of respondents gave a scoring score of 7, from a scale of 1-10.

6. Results of Toll Road Business Entity Performance in the Last Two Years

a. The Impact of Human Resource Quality on Company Performance

Almost all respondents agreed that the quality of human resources greatly affects the company's performance. A score of 7 was given by $43.5 \%$ and a score of 9 was given by $48.1 \%$ of respondents.

b. The Effect of the Covid-19 Pandemic on the Company's Business Flow

Land acquisition and construction implementation in the field is the main business flow in TRBE. More than $50 \%$ of respondents agreed that the company's main business flow was disrupted due to the covid-19 pandemic. $61.1 \%$ of respondents gave a score of 7 against the land acquisition process, while $50.9 \%$ of respondents gave a score of 8 on the implementation of construction in the field. Labor-intensive systems are becoming a common practice in the construction world. This practice is contrary to the government's advice to maintain distance. However, all respondents said they did not agree that construction progress should be stopped during the Covid-19 pandemic. $40.7 \%$ of respondents gave a score of $3,31.5 \%$ gave a score of 2 , and the rest strongly disagreed if construction was stopped, namely by giving a score of 1 .

c. Impact of the Covid-19 Pandemic on Legal Aspects of Business Flow

The covid-19 pandemic limited the mobilization of people and goods. Meanwhile, the mobilization of both is urgently needed to support the construction process. So that the restriction of mobilization has an impact on price fluctuations and changes of construction work schedule. Most respondents agreed that renegotiation of contract prices could be made. $41.7 \%$ of respondents gave a score of $7,47.2 \%$ gave a score of 8 , and $11.1 \%$ gave a score of 9 . A total of $51.9 \%$ of respondents also approved if the contractor and owner agreed to addendum of extension.

d. Involvement of Various Parties During the Covid-19 Pandemic

Construction activities generally involve three parties, namely service users, service providers, and supervisory consultants. All three must consolidate in order to prepare Covid-19 prevention procedures in the project environment. A total of $75.9 \%$ of respondents gave a score of 9 in this scope.

\section{NVIVO Data Analysis}

Quantitative research tells us how often or how many things behave in a particular way. However, when we want to expand or deepen our understanding of how things become as they are in our social world, qualitative research has no substitute. Qualitative research usually produces large amounts of textual data in the form of transcripts and field records. Systematic and rigorous preparation and analysis of qualitative data is usually time and effort 
consuming. To reduce this burden, it is important for the study to be aware of the possible use of NVivo 12 .

\section{Cases}

In the NVIVO application, (Cases) is a node representing an 'observation unit' e.g., an interviewee or a studied community. Projects on this study may have case nodes for people, places, organizations, events, or other entities. Cases differ from other nodes in that they can have attributes (variables) such as age, gender or location. Using queries, the app can compare cases based on these attributes. In this section, interviews have been conducted on 13 informants who can be used as sources to find out the implementation of projects during the covid-19 pandemic, especially related to EOSH. The image below explains a concept map based on informants regarding the relationship of answers between informants with each other according to similarities, symmetrical arrows indicate that between one cases with each other has a close relationship or has more or less the same answer.

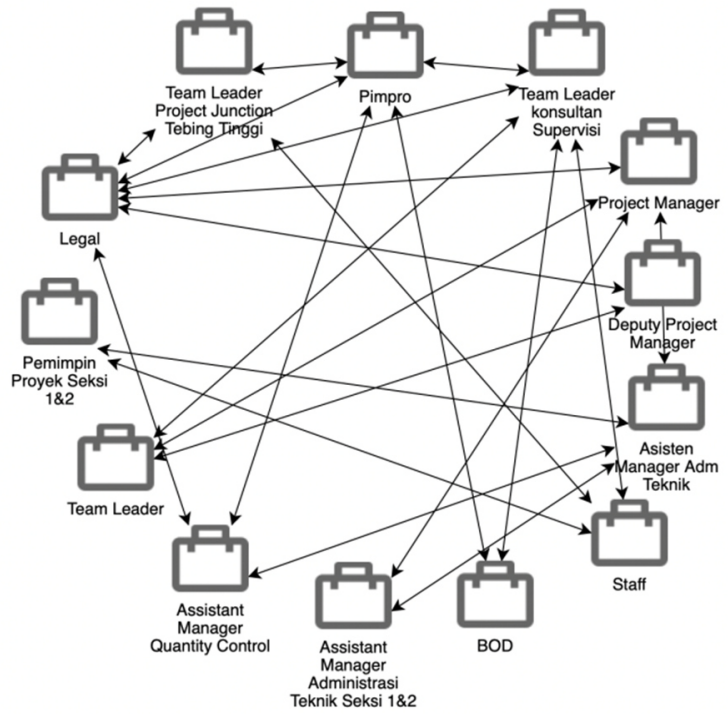

Figure 8 NVIVO Application

The implementation of the project was constrained by very severe conditions, namely the emergence of the Covid-19 pandemic where the disease outbreak spread very quickly that it greatly disrupted the project development process in the field. It can be known that each department and each position that is quite diverse consisting of 13 different posts are addressing obstacles to projects that run in their own way and have different opinions from each other. However, they have the same purpose, especially in EOSH and prevention of the spread of the covid-19 virus that can interfere with the running of the project.

Integration between positions becomes the company's power to prevent the impact of covid-19 on the process of running the project as a mitigation measure. In the above section of the Section Project Leader and Project Leader being one of the sources of informants who have the same relationship with other positions. This indicates that both positions or position roles are very central to the integration of positions in carrying out the company's strategy during the covid-19 pandemic, especially related to human resource management in realizing Environmental Occupational Safety and Health (EOSH).

\section{Coding}

Coding in qualitative research is a word or phrase that summarizes or captures the essence of some data. Coding is an analytical process for categorizing data. In NVivo, coding is the process of collecting related material into containers called Node.js. When a researcher opens a node, the researcher can see all the references in the project encoded to that node. There are several types of code in NVivo. Theme nodes are code that represents themes or topics that can be found in research data. The relationship records the relationship between two project items. Sentiment codes are positive and negative nodes created by automatically encoding sentiments. NVivo supports deductive (predefined coding schemes, often based on themes emerging from literature reviews) and inductive (code generated when examining collected data) approaches to coding.

In concept map, there is a description to the answers from interview results in 13 different informant sources that most informant sources relate HR problems to certain themes, namely: a) HR rules; b) Late HR Management; c) Mapping Needs; d) HR monitoring; e) Mobilization of Personnel; f) HR Key to Success; g) Socialization; h) Circular Letter of the Minister of Manpower; i) HR Stress Management; j) HR control over EOSH; k) Decrease in HR Performance; 1) Technical Guidance; m) HR Performance Targets; and n) HR's Largest Asset.

In concept map, there is also a description to the answers from interview results in 13 different informant sources that most informant sources relate the problem of Rapid Response to certain themes namely: a) Innovation; b) Task Force; c) Lack of Responsiveness; d) Establishment of Task Force; e) Health Protocols; f) Rapid Antigen; 
g) Preventive Response; h) Situation Response; and i) Meeting Room Partition.

The concept map describes the answers from interviews to 13 different informant sources that most informant sources relate EOSH problems to certain themes: a) Construction Safety Analysis; b) CSA and JSA; c) EOSH discipline; d) Top Management Support; e) Evaluation of EOSH Activities; f) Occupational Safety Awareness; g) Coordination and Communication; h) Lack of EOSH Training; i) EOSH Financing Issues; j) Incomplete use of PPE; k) Implementation of EOSH System; 1) Clean and Healthy Living Behaviors; m) Certification Program; $n$ ) Health Procedures; o) Regulations; p) Standards; and q) Not following EOSH SOP.

The concept map also describes the answers from interview results in 13 different informant sources that most informant sources relate the issue of Responsibility to certain themes namely: a) Director; b) General Manager of Engineering; c) Technical General Manager and Project Leader; d) HRD and Management; e) EOSH Manager; f) EOSH and HR Managers; g) The Company's Chairman; h) Project Leader; i) HR EOSH Field; and j) All Employees.

In concept map, there is a description to the answers from interview results on 13 different informant sources in that most informant sources relate WFH problems to certain themes: a) Online; b) Collaboration; c) New Normal; d) Restriction of Wiggle Room; e) Technology; f) Teleconference.

\section{Word Frequency Queries}

The Usage of Word Frequency Query is to create a list of words or concepts that appear most frequently in research. This study used Word Frequency Queries to: Identify possible themes, particularly in the early stages of a project to analyze the words most commonly used in a given demographic. For example, analyzing the words most commonly used by informants. This research can perform coding queries to collect all the contents encoded on a case node with an informant source attribute consisting of 13 people, then select the result node as the criteria for the Word Frequency Query.

\section{Word Tree}

Ben Shneiderman introduced the word Tree in the early 90s as a visualization metaphor for displaying hierarchical trees. Word tree organizes hierarchical items that represent the structure of the tree. The root line of the word tree is called a cell. A word tree is a visualization that displays text data hierarchically: as an element tree, usually a single word, is connected by a line. This type can be used to denote the typical context in which the basic word appears or the hierarchy of terms. Using interactive word tree, words and word combinations can be explored and analyzed visually in their respective contexts. The more often a word or word combination appears, the clearer it appears on a tree. The Word Tree offers two-way interactivity: Firstly, it can be navigated through its individual "branches" to visualize words in context. Secondly, the data is interactively related to the original text, so that this dissertation can present words and phrases.
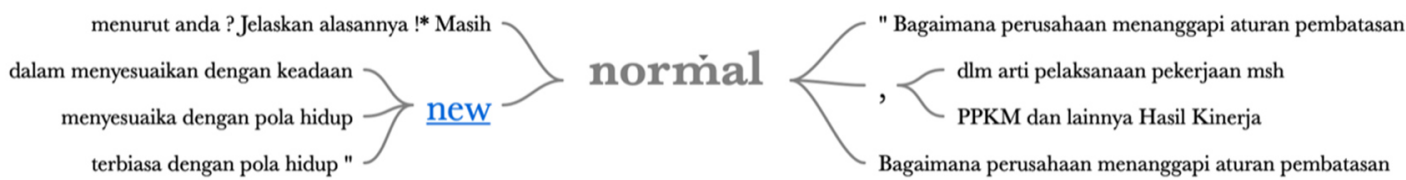

In the Word Tree image, it is explained that in the interview results by 13 informants discussing the theme "New Normal" is one of the most discussed themes or the word is one of the most widely used in the answers of informants, this data uses 13 interview results that have different outputs but the direction of conversation and opinions of informants tend to have similarities regarding the topic of the problem they are talking about. "New Normal" which can be seen in several phrases regarding the imposition of restrictions on community activities (PPKM), lifestyle, performance results, and restriction rules.

In the interview results by 13 informants discussing the "Prevention" theme is one of the most discussed themes or the word is one of the most widely used in the answers of informants, this data uses 13 interview results that have different outputs but the direction of conversation and opinions of informants tend to have similarities regarding the topic of the problem they are talking about, namely about "Prevention" which can be seen in several phrases regarding the company anticipation and pandemic Covid-19.

In the results of interviews by 13 informants discussing the "Protocol" theme is one of the most discussed themes or the word is one of the most widely used in the answers of informants, this data uses 13 interview results that have different outputs but the direction of conversation and opinions of informants tend to have similarities regarding the topic of the problem they are talking about, namely about "Protocol" which can be seen in several phrases regarding health, task force covid, awareness, and work standards.

In the interview results by 13 informants discussing the "Project" theme is one of the most discussed themes or the word is one of the most widely used in the answers from informants, this data uses 13 interview results that have different outputs but the direction of conversation and opinions of informants tend to have similarities regarding the topic of the problem they are talking about, namely about "Project" which can be seen in several 
phrases about the dynamics of the problems affecting implementation, must be achieved based on work schedule, and also the need for resource management.

In the results of interviews by 13 informants discussing the "Health" theme is one of the most discussed themes or the word is one of the most widely used in the answers of informants, this data uses 13 interview results that have different outputs but the direction of conversation and opinions of informants tend to have similarities regarding the topic of the problem they are talking about, namely about "Health" which can be seen in several phrases regarding safety, work, environment, and the execution of system implementation.

In the interview results by 13 informants discussing the "Covid" theme is one of the most discussed themes or the word is one of the most widely used in the answers from informants, this data uses 13 interview results that have different outputs but the direction of conversation and opinions of informants tend to have similarities regarding the topic of the problem they are talking about, namely about "Covid" which can be seen in several phrases regarding pandemic, virus spread, decreased performance of TRBE, Task Force, HR Monitoring, and Innovation to conduct Rapid Antigen.

In the interview results by 13 informants discussing the "HR" theme is one of the most discussed themes or the word is one of the most widely used in the answers of informants, this data uses 13 interview results that have different outputs but the direction of conversation and opinions of informants tend to have similarities regarding the topic of the problem they are talking about, namely about "HR" which can be seen in several phrases regarding implementation, management of HR, HR obstacles, and the company's largest assets.

In the interview results by 13 informants discussing the "EOSH" theme is one of the most discussed themes or the word is one of the most widely used in the answers of informants, this data uses 13 interview results that have different outputs but the direction of conversation and opinions of informants tend to have similarities regarding the topic of the problem they are talking about, namely about "EOSH" which can be seen in several phrases regarding system implementation, work environment, responsibilities, and clean \& healthy life behaviour.

\section{Conclusion}

Based on previous studies and research results, it can be concluded that:

1. Implementation of the Environmental Occupational Safety and Health System before and after the Covid-19 pandemic. Environmental Occupational Safety and Health System is absolutely necessary in every industry, especially in the field of construction. The construction industry is full of high-risk jobs. So the Environmental Occupational Safety and Health System needs to be carefully designed before work begins.

2. Management of Human Resource competencies in the field of Environmental Occupational Safety and Health. Human resource is the main asset of a company, it needs to be regenerated periodically. In addition, the field of Environmental Occupational Safety and Health certainly has a target in supporting the working of a company. To achieve this target, it is necessary to have human resource who has the passion to achieve the target.

3. Innovation of Toll Road Business Entity in the Field of Environmental Occupational Safety and Health in Facing Challenges. In the dynamics of a market that moves rapidly and erratically day by day, innovation is the key. With innovation, the company can still survive in changing times. Similarly with the COVID-19 pandemic that hit Indonesia, making a lot of companies to review their strategies in order to survive.

4. Toll Road Business Entity Performance Results in the last 2 years. Human resources in the current era are seen as a valuable asset of a company. The performance of human resources provides the largest contribution to the company's performance. The COVID-19 pandemic has forced work activities to be carried out remotely (Work From Home). This gives a decline in performance in the last two years.

\section{Suggestions}

This research is structured in such a way that it is expected to be able to provide a new perspective on the relationship between human resources and the Environmental Occupational Safety and Health system during the Covid-19 pandemic. The rapidly changing condition of the Covid-19 pandemic certainly has a different impact from time to time. Thus, to maximize similar research in the future, the authors recommend the following:

1. The research should focus on the time dimension more specifically, considering conditions change very quickly.

2. Because the COVID-19 pandemic has different impacts in each field, research on the impact of Covid-19 should also be carried out in a narrower scope.

3. Researchers need to follow the development of the issuance of new regulations from the government as a basis for analyzing research.

4. Similar research on multinational companies is feasible, to find out the response of other countries to economic activities held in Indonesia. 


\section{REFERENCES}

A. Handayani, M.I. (2017). Perencanaan Perekrutan Kriteria Sumber Daya Manusia PT Varia Usaha Beton (Studi Kasus Pada Proyek Pembangunan Jalan Tol Dan Pusat Perbelanjaan). Jurnal Spread, 7(2008), 159-170.

Abdullah, Z. (2018). Analisis Pengaruh Keselamatan Dan Kesehatan Kerja (K3) Terhadap Kinerja Pekerja Konstruksi (Studi Kasuss Proyek the Manhattan Mall \& Condominium). Teras Jurnal, 8(1), 329. https://doi.org/10.29103/tj.v8i1.144

Almira, D., Dardiri, A., \& Isnandar, I. (2016). Kompetensi Lulusan SMK Program Keahlian Teknik Bangunan Kompetensi Keahlian Teknik Konstruksi Batu dan Beton yang Dibutuhkan Industri Jasa Konstruksi di Jawa Timur. Jurnal Pendidikan: Teori, Penelitian, Dan Pengembangan, 1(4), 673-680.

Andi Andi, \& Dwi Djendoko. (2004). Motivasi Pekerja Pada Beberapa Proyek Konstruksi Di Surabaya. Civil Engineering Dimension, 6(2), pp.80-87.

Andriani, R. (2014). Pengaruh Budaya Organisasi Dan Kompetensi Terhadap Kepuasan Kerja Karyawan Pada Bank Tabungan Negara Di Bandung. Jurnal Ekonomi, Manajemen Dan Bisnis, II(2), 247-257.

Anugrahana, A. (2020). Hambatan, Solusi dan Harapan: Pembelajaran Daring Selama Masa Pandemi Covid-19 Oleh Guru Sekolah Dasar. Scholaria: Jurnal Pendidikan Dan Kebudayaan, 10(3), 282-289.

Bram, A. (2017). Pengaruh Kompetensi, Pengalaman Kerja dan Penempatan Terhadap Komitmen Organisasi PT. Wahana Meta Riau di Pekanbaru. Jom Fekom, 4.

Brown, A. P. (2010). Qualitative method and compromise in applied social research. Qualitative Research, 10(2), $229-248$.

Busyairi, M., Ode, L., \& Safar, A. (2014). Pengaruh Keselamatan Kerja Dan Kesehatan Kerja Terhadap Produktivitas Kerja Karyawan. Jurnal Ilmiah Teknik Industri, 13(02), 302-304. https://doi.org/10.1055/s0032-1326702

Chandra, A. R. S. A. A. (2005). Model Persamaan Struktural Pengaruh Budaya Keselamatan Kerja pada Perilaku Pekerja di Proyek Konstruksi. Jurnal Teknik Sipil, 12(3).

Cieślik, A., Qu, Y., \& Qu, T. (2018). Innovations and export performance: Firm level evidence from China. Entrepreneurial Business and Economics Review, 6(4), 27-47. https://doi.org/10.15678/EBER.2018.060402

Darmaningrat, E. W. T., Astuti, H. M., \& Rizqy, A. I. (2019). Analisis Kesenjangan dan Pemodelan Proses Bisnis Human Capital Management pada PTPN XI berdasarkan Best Practice SAP. Jurnal Teknologi Informasi Dan Ilmu Komputer, 6(2), 187. https://doi.org/10.25126/jtiik.201962937

Darsono Pawironegoro dan Dewi Utari. (2016). Manajemen Sumber Daya Manusia Abad 21 Kajian tentang Sumber Daya Manusia secara Filsafat, Ekonomi, Sosial, Antropologi, dan Politik. Jakarta: Mitra Wacana Media.

Darwati, Dr. S. (n.d.). Demontrasi yang Dilakukan Oleh Serikat Pekerja/Serikat Buruh, Berdasarkan Undangundang Nomor 9 Tahun 1998 Tentang Kemerdekaan Menyampaikan Pendapat di Muka Umum. Lex Librum: Jurnal Ilmu Hukum, 151(september 2016), 257-277. https://doi.org/10.1145/3132847.3132886

Dessler, G. (2010). Human Resource Management: The Strategic Role of Human Resource Management. Prentice Hall, Inc.: NJ, NJ.

Dewi, A. S. (2016). Budaya Berbagi Pengetahuan Dan Pengembangan Sumber Daya Manusia: Kasus Gerakan Free Software dan Dounjinshi Culture. Jurnal Sosiologi Reflektif, $10(2), 85$. https://doi.org/10.14421/jsr.v10i2.1155

Diah Handayani, Dwi Rendra Hadi, Fathiyah Isbaniah, Erlina Burhan, H. A., \& Departemen. (2020). Corona Virus Disease 2019. Jurnal Respirologi Indonesia, 40(1), 9-12.

Diyandhari, K., \& Kismono, G. (2020). Intensi Menggunakan Msdm-E Mobile, Faktor Yang Memengaruhi Dan Peran Kemampuan Menggunakannya: Model Analisis Jalur. Jurnal Ilmiah Manajemen, 10(2), 285. https://doi.org/10.22441/mix.2020.v10i2.010

Edy Sutrisno. (2015). Manajemen Sumber Daya Manusia (1st ed.). Kencana Prenadamedia Group.

Erhamwilda, E. (2005). Mengubah Budaya Kerja Sebagai Upaya Meningkatkan Kualitas Bangsa. MIMBAR, Jurnal Sosial Dan Pembangunan, 21(4), 578.

Etikawati, E., \& Udjang, R. (2016). Strategi Rekrutmen Dan Seleksi Terhadap Kinerja Karyawan. Jurnal Perilaku Dan Strategi Bisnis, 4(1), 9-23. https://doi.org/10.26486/jpsb.v4i1.443

Gusti Ayu Putu Candra Dharmayanti, Ida Bagus Rai Adnyana, M. A. N. (2020). Pengaruh Kinerja Sumber Daya Manusia Terhadap Kinerja Proyek Konstruksi Di Kabupaten Badung. Jurnal Ilmiah Teknik Sipil, 24.

Hadijah, I. (2014). Upaya Peningkatan Export Drive Industri Fashion di Era Globalisasi. Jurnal Teknologi Dan Kejuruan, 37, No. 1(1), 95-108.

Hammersley, M. (2018). The dilemma of qualitative method: Herbert Blumer and the Chicago tradition. Routledge.

Harmon Zubadi. (2009). Perencanaan Strategi Bersaing Melalui Strategi Sumber Daya Manusia. Jurnal Analisis Bisnis Dan Ekonomi, 8(2), 201-221.

Haromain. (2013). Manajemen Pengembangan Sumber Daya Manusia (SDM) Pondok Pesantren. Jurnal 
Pendidikan Humaniora, 1(2), 136-149.

Hastangka, \& Farid, M. (2020). Kebijakan Politik Presiden Jokowi Terhadap Masalah Kewarganegaraan Dalam Merespons Isu Global: Studi Kasus Covid-19. Citizenship: Jurnal Pancasila Dan Kewarganegaraan, 8(1), $1-13$.

Imasiku, K., Thomas, V. M., \& Ntagwirumugara, E. (2020). Unpacking Ecological Stress from Economic Activities for Sustainability and Resource Optimization in Sub-Saharan Africa. Sustainability (Switzerland), 12(9), 1-12. https://doi.org/10.3390/SU12093538

International Labour Organization. (2020). Dalam menghadapi pandemi: Memastikan Keselamatan dan Kesehatan di Tempat Kerja. Labour Administration, Labour Inspection and Occupational Safety and Health Branch (LABADMIN/OSH) Route, 1-52.

Irfan Wahid, M. (2020). Dari Tradisional Menuju Digital: Adopsi Internet Oleh Nahdlatul Ulama Selama Pandemi Covid-19. Jurnal Studi Agama Dan Masyarakat, 16(1), 73-84. https://doi.org/10.23971/jsam.v16i1.1745

Jaedun, M. W. A. (2019). Relevansi Kompetensi Lulusan Kejuruan Teknik Bangunan Untuk Bekerja Di Industri Konstruksi. Jurnal Kependidikan, 3, 81-94.

Jufri, Z. K. (2018). Kompetensi Sumber Daya Manusia Di Kantor Sistem Administrasi Manunggal Satu Atap ( Samsat ) Wilayah. Jurnal Administrasi Negara, 5(2), 1-9.

Kagermann, H., Wahlster, W., Helbig, J., Hellinger, A., Stumpf, M. A. V., Treugut, L., Blasco, J., Galloway, H., \& Findeklee, U. (2013). Securing the future of German manufacturing industry: Recommendations for Implementing The Strategic Initiative Industrie 4.0. In Acatech National Academy Of Science and Engineering (Issue April).

Khanafi, I., Salafuddin, S., Abidin, M. Y., \& Khamidi, A. N. (2013). Persepsi dan Transformasi Visi dan Misi Pada Civitas Akademika Stain Pekalongan. Jurnal Penelitian, 6(2).

Kristanto, Y. D., Fahmi, I., \& Maulana, A. (2015). Pengembangan Kamus Kompetensi Keselamatan Kerja Di PT Xyz Indonesia Tbk. Jurnal Aplikasi Bisnis Dan Manajemen, 3(1), 1-11. https://doi.org/10.17358/jabm.3.1.1

Muflihah, S., \& Pudjihardjo, H. S. (2019). Analisis Manajemen Risiko Keselamatan Dan Kesehatan Kerja (K3) Pada Proyek Pembangunan Gedung Di Semarang. Teknika, 14(2), 54. https://doi.org/10.26623/teknika.v14i2.1805

$\mathrm{Ng}, \quad$ S. (2020). Menulis Pandemi. Indonesian Journal of Cardiology, 41(2), $43-45$. https://doi.org/10.30701/ijc.1026

Pesulima, T. L., \& Hetharie, Y. (2020). Perlindungan Hukum Terhadap Keselamatan Kerja Bagi Tenaga Kesehatan Akibat Pandemi Covid-19. Sasi, 26(2), 280. https://doi.org/10.47268/sasi.v26i2.307

Pfeiffer, S. (2017). The Vision of "Industrie 4.0" in the Making-A Case of Future Told, Tamed, and Traded. NanoEthics, 11(1), 107-121. https://doi.org/10.1007/s11569-016-0280-3

Pratikto, F. R. (2020). Prediksi Akhir Pandemi COVID-19 di Indonesia dengan Simulasi Berbasis Model Pertumbuhan Parametrik. Jurnal Rekayasa Sistem Industri, 9(2), 63-68. https://doi.org/10.26593/jrsi.v9i2.4018.63-68

Presiden Republik Indonesia. (2003). Undang-Undang Nomor 13 Tahun 2003 pasal 1 ayat 1 tentang Ketenagakerjaan.

Purnamasari, I., Munjin, R. A., \& Ratnamulyani, I. A. (2019). Penataan Sumber Daya Manusia Aparatur Daerah Berbasis Kompetensi. Jurnal Governansi, 5(1), 70. https://doi.org/10.30997/jgs.v5i1.1707

Purnamasari, O. D. H. I. (2019). Analysis Of Human Resource Competency In Local Office Of Public Work And Spatial Planning In Bogor City. Jurnal Governansi, 5, 149-156.

Riana, A., Hendriani, S., \& Efni, Y. (2018). Pengaruh Pendidikan Dan Pelatihan, Remunerasi Dan Budaya Organisasi Terhadap Kepuasan Kerja Dalam Meningkatkan Kinerja Pada Dit Reskrimsus Polda Riau. Jurnal Psikologi, 13(2), 98. https://doi.org/10.24014/jp.v13i2.4242

Rusilowati, U. (2020). Praktek Manajemen Sumber Daya Manusia selama Pandemi COVID-19 pada Karyawan yang Bergerak di Sektor Formal di Indonesia. Jurnal Ilmiah MEA (Manajemen, Ekonomi, \& ..., 4(2), 481491.

Sahadi, S., \& Agung Wibowo, M. (2015). Ketepatan Klasifikasi pada Pengelompokan Manajer Proyek Konstruksi Berdasarkan Faktor Pengembangan Sumber Daya Manusia Menggunakan Analisis Diskriminan. Media Komunikasi Teknik Sipil, 20(2). https://doi.org/10.12777/mkts.20.2.119-124

Saidah, I. (2020). Implementasi Supervisi Manajerial melalui Penyusunan Visi Misi TK dengan Metode Delphi. Aulad : Journal on Early Childhood, 3(1), 1-7. https://doi.org/10.31004/aulad.v3i1.44

Sholehatusya Diah. (2017). Pegaruh Kompetensi Kerja Terhadap Kinerja Karyawan Dikantor PT. Kitadin Tenggarong Seberang. E- Jurnal Administrasi Negara, 5(2), 5791.

Sumardjito. (n.d.). Suatu Tinjauan Terhadap Sistem dan Mekanisme Kerja Proyek Konstruksi di Indonesia. Cakrawala Pendidikan, 2.

Suryaningtyas, D. (2013). Analisis Pengaruh Kompetensi Terhadap Peran-Peran Baru Profesional Sumber Daya Manusia. Modernisasi, 9, 169-190. 
Susihono, W., \& Rini, F. A. (2013). Penerapan Sistem Manajemen Keselamatan dan Kesehatan Kerja (K3) dan Identifikasi Potensi Bahaya Kerja (Studi kasus di PT. LTX Kota Cilegon- Banten). Spektrum Industri, 11(2), 209. https://doi.org/10.12928/si.v11i2.1663

Triyonggo, Y., Maarif, M. S., Sukmawati, A., \& Baga, L. M. (2015). Analisis Situasional Kompetensi Praktisi Sumber Daya Manusia Indonesia Menghadapi MEA 2015. Jurnal Manajemen Teknologi, 14(1), 100-112. https://doi.org/10.12695/jmt.2015.14.1.7

Tupamahu, F. A. S. (2015). Integrasi Budaya Terhadap Kapabilitas Dan Keunggulan Kompetitif Berkelanjutan. Conference in Business, Accounting, and Management, 53-69.

Virgana. (2019). The Increasing Performance of School Principal Through Remuneration, Personality, and Job Satisfaction. IJHCM (International Journal of Human Capital Management), 2(2), 45-59. https://doi.org/10.21009/ijhcm.02.02.05

Waruwu, S., \& Yuamita, F. (2016). Analisis Faktor Kesehatan Dan Keselamatan Kerja (K3) Yang Signifikan Mempengaruhi Kecelakaan Kerja Pada Proyek Pembangunan Apartement Student Castle. Spektrum Industri, 14(1), 63. https://doi.org/10.12928/si.v14i1.3705

Wibowo. (2016). Manajemen Kinerja (5th ed.). Raja Grafindo Persada.

Wibowo, A., Pradiptha, A. P., Mulyati, M., \& Utari, D. R. (2020). Penyuluhan Wirausaha Berbasis Teknologi untuk Pemulihan Ekonomi Masyarakat Terdampak Covid-19 di Masa New Normal. E-Dimas: Jurnal Pengabdian Kepada Masyarakat, 11(3), 357-365. https://doi.org/10.26877/e-dimas.v11i3.5872

Widodo S. E. (2015). Manajemen Pengembangan Sumber Daya Manusia (Pustaka Pe). Yogyakarta: Pustaka Pelajar.

Widowati, A. A. E. (2016). Evaluasi Penerapan ABg (Aktif Berbagi) Sistem Sebagai Upaya Mengurangi Angka Kecelakaan Kerja di PT Coca-Cola Amatil Indonesia Central Java. Unnes Journal Of Public Health, 3(1), 110.

Wiresti, R. D. (2020). Analisis Dampak Work From Home pada Anak Usia Dini di Masa Pandemi Covid-19. Jurnal Obsesi : Jurnal Pendidikan Anak Usia Dini, 5(1), 641. https://doi.org/10.31004/obsesi.v5i1.563

Yulianto, Much. (2016). Peran Budaya Organisasi Dalam Mewujudkan Visi Misi Partai Keadilan Sejahtera (PKS). Jurnal Ilmu Sosial, 15(2), 90. https://doi.org/10.14710/jis.15.2.2016.90-102

Zuraidah, E. (2018). Knowledge Management System Untuk SDM Menggunakan Seci Model (Studi Kasus: Koperasi Karyawan). Jurnal Informatika, 5(1), 157-168. https://doi.org/10.31311/ji.v5i1.2481 